\title{
Effects of $\beta$-hydroxybutyrate and different calcium and potassium concentrations on the membrane potential and motility of abomasal smooth muscle cells in cattle
}

\author{
L. Zurr and S. Leonhard-Marek ${ }^{1}$ \\ Department of Physiology, University of Veterinary Medicine Hannover, Bischofsholer Damm 15, 30173 Hannover, Germany
}

\begin{abstract}
The left displacement of the abomasum (LDA) is a common disease in periparturient dairy cows. Plasma $\beta$-hydroxybutyrate (BHBA) levels above the reference range are regarded as risk factors for the occurrence of LDA. Additionally, hypokalemia and hypocalcemia have been observed in LDA cows. The aim of the present study was to characterize the membrane potential and the slow waves in abomasal smooth muscle cells by a microelectrode technique and to determine possible effects of BHBA and of various calcium and potassium concentrations on the membrane potential. Subsequently, the results obtained by the microelectrode technique were combined with in vitro motility experiments of abomasal smooth muscles. Strips of the abomasal circular smooth muscles were prepared and incubated in different buffer solutions. For the microelectrode technique, healthy bulls and cows that underwent surgery for LDA were sampled. These measurements showed a frequency of the slow waves between 3.5 and 10.9 per minute (for amplitudes $\geq 3 \mathrm{mV}$ ) and between 0.6 and 4.5 per minute (for amplitudes $\geq 5 \mathrm{mV}$ ). The frequency of contractions (1.8 to 3.1 per minute) were in the same order as the frequency of the slow waves with amplitudes $\geq 5 \mathrm{mV}$. Blocking potassium conductance with barium chloride induced a depolarization of the basal membrane potential (from $-43 \pm 2.9$ to $-37 \pm$ $4.1 \mathrm{mV}$; mean \pm standard error of the mean) without affecting the frequency or the height of the slow waves. The reduction in the potassium concentration from 5.4 to $2 \mathrm{mmol} / \mathrm{L}$ resulted in a nominal decrease in the activity of contractions (from 22.2 to $18.6 \mathrm{mN} / \mathrm{min}$ ). The subsequent addition of $1 \mathrm{mmol}$ of $\mathrm{KCl} / \mathrm{L}$ induced a nominal increase in contraction activity (from 18.6 to $25.7 \mathrm{mN} / \mathrm{min})$. An effect of BHBA (5 mmol/L) could not be demonstrated, neither on the electric nor on
\end{abstract}

Received February 28, 2012.

Accepted June 25, 2012.

${ }^{1}$ Corresponding author: sabine.leonhard-marek@tiho-hannover.de the motility parameters. A simulated hypocalcemia $(1.2 \mathrm{mmol} / \mathrm{L}$ total, $0.9 \mathrm{mmol} / \mathrm{L}$ ionized $\mathrm{Ca})$ did not change slow waves and motility. In conclusion, changes in membrane potential $\geq 5 \mathrm{mV}$ correlated with contractions of abomasal muscles. Hypokalemic conditions may reduce abomasal contraction activity via an effect on the membrane potential. An exclusive increase in BHBA or a slight hypocalcemia $(0.9 \mathrm{mmol} / \mathrm{L}$ ionized Ca) had no effects on the motility of healthy abomasal smooth muscle cells. A prolonged or severe exposition of muscles to a combination of low $\mathrm{Ca}$ and high BHBA concentrations might nevertheless be able to affect abomasal motility.

Key words: displaced abomasum, ketonemia, hypocalcemia, hypokalemia

\section{INTRODUCTION}

The left displacement of the abomasum (LDA) is a common disease in high-yielding dairy cows (Constable et al., 1992; Stengärde et al., 2010). The pathogenesis is characterized by hypomotility of the abomasal smooth muscles. A subsequent gas accumulation in the fundus of the abomasum may result in a displacement of the abomasum (Constable et al., 1992; Geishauser, 1995). Abomasal smooth muscle contractility is based on slow waves: membrane potential alterations are initiated by the interstitial cells of Cajal (ICC). These are pacemaker cells that generate pacemaker potentials (Suzuki, 2000; Kito and Suzuki, 2003). Electrical potential changes are transmitted to the gastric smooth muscle cells via peg and socket junctions, which connect one smooth muscle cell to a second one or to an ICC by an invagination of the plasma membrane (Garcia-Lopez et al., 2009). The enteric nervous system is able to modulate the slow wave activity by transmitters influencing ion channels (Rolle et al., 2007).

Many factors are involved in the development of LDA. Among these, high blood concentration of FFA and even more an increase in the ketone body BHBA above reference range are both associated with an increased risk for cows to develop LDA (Geishauser et al., 
1997; LeBlanc et al., 2005). Additionally, hypokalemia, hypocalcemia, and insulin resistance were observed in cows that developed LDA (Massey et al., 1993; Stengärde et al., 2010). Nevertheless, it is not known whether LDA is a result of several factors or only one factor. Whereas hypokalemia and hypocalcemia might be cause or consequence of LDA, hypochloremia seems to be a mere consequence of LDA (Ward et al., 1994).

In vitro studies have demonstrated that the activity of the abomasal smooth muscles are affected by different parameters: decreased extracellular potassium concentration (between 5 and $1 \mathrm{mmol} / \mathrm{L}$ ) or increased insulin concentration in the incubation buffer (to 21 $\mathrm{mU} / \mathrm{L}$ or higher) decreased the activity of abomasal smooth muscle cells (Türck and Leonhard-Marek, 2010). In vivo, a decreased calcium concentration in blood (from 2.6 to $1.2 \mathrm{mmol} / \mathrm{L}$ ) initiated abomasal hypomotility (Daniel, 1983).

The aim of the present study was to further investigate hypocalcemia and ketosis as predisposing factors to contribute to the understanding of the pathogenesis of LDA. To this end, the membrane potential and the frequency of slow waves in bovine abomasal smooth muscle cells were characterized by a microelectrode technique, and effects of BHBA and various calcium concentrations in the buffer solution were evaluated. These microelectrode studies were combined with in vitro motility experiments of abomasal smooth muscles. The question to answer was if a simulated ketosis or subclinical hypocalcemia might impair the slow wave activity and the motility of the abomasal smooth muscle cells.

\section{MATERIALS AND METHODS}

\section{Animals}

Tissue samples of the abomasal corpus were obtained at slaughter from 33 healthy bulls (beef bred) at a local abattoir. Thirty minutes after slaughtering abomasal tissue samples were obtained from animal carcasses without macroscopic pathological alterations. The tissue samples were transported and stored at $6^{\circ} \mathrm{C}$ in chilled Krebs-Henseleit $(\mathbf{K H})$ buffer $(113.6 \mathrm{mmol}$ of $\mathrm{NaCl} / \mathrm{L}$, $5.4 \mathrm{mmol}$ of $\mathrm{KCl} / \mathrm{L}, 1.2 \mathrm{mmol}$ of $\mathrm{CaCl}_{2} / \mathrm{L}, 1.2 \mathrm{mmol}$ of $\mathrm{MgCl}_{2} / \mathrm{L}, 0.2 \mathrm{mmol}$ of $\mathrm{HCl} / \mathrm{L}, 0.6 \mathrm{mmol}$ of $\mathrm{NaHPO}_{4} / \mathrm{L}$, $2.4 \mathrm{mmol}$ of $\mathrm{Na}_{2} \mathrm{HPO}_{4} / \mathrm{L}, 21 \mathrm{mmol}$ of $\mathrm{NaHCO}_{3} / \mathrm{L}$, $10 \mathrm{mmol}$ of glucose/L, and $3.6 \mathrm{~g}$ of mannitol/L). For comparison, abomasal muscle samples were taken from 5 cows that underwent LDA surgery by the Dirksen (1967) method (Hannover method; laparotomy with omentopexy) in the clinic for cattle. All cows had been diagnosed with LDA. Three out of 5 cows had been treated on their hooves before laparotomy, had been rolled over, and showed no longer a displaced abomasum during the operation. The blood calcium concentration before surgery ranged between 1.95 and 2.35 $\mathrm{mmol} / \mathrm{L}$ (reference range: $2.1-2.8 \mathrm{mmol} / \mathrm{L}$ ). The urine samples of these cows tested negative for ketone bodies. The abomasal muscle samples obtained during surgery were transported and stored as the bull samples.

\section{Preparation of the Smooth Muscle Samples}

Mucosa and submucosa were dissected and removed from the underlying muscle layers. Thereafter, circular muscle layers were facing upwards. Muscle strips of $0.5 \times 1 \mathrm{~cm}$ were prepared and pinned into a small incubation chamber. Circular smooth muscle cells were impaled with microelectrodes. During the preparation and in the incubation chamber the tissue was perfused with $\mathrm{KH}$ buffer at room temperature.

\section{Microelectrode Technique}

The microelectrodes were produced by the following protocol: A glass capillary (GB 150F-8P with filament; Science Products GmbH, Hofheim, Germany) was inserted into a Needle Pipette Puller (model 750, Kopf TM; Bachofer Laboratoriumsgeräte, Reutlingen, Germany). The resulting microelectrodes were charged with $0.5 \mathrm{M} \mathrm{KCl}$. Only microelectrodes with an electric resistance between 50 and $80 \Omega$ were used for measurements of the membrane potential changes.

The tissue dish for microelectrode experiments (capacity for buffer solution: $2 \mathrm{~mL}$ ) was fixed on a heightadjustable stand and constant buffer perfusion was maintained by storage containers, which were gassed with $95 \% \mathrm{CO}_{2}$ and $5 \% \mathrm{O}_{2}$ at room temperature. The microelectrode was installed on a rack, which was mobile in all directions. A reference electrode $(\mathrm{Ag} / \mathrm{AgCl}$ standing in $3 \mathrm{M} \mathrm{KCl}$ ) was connected to the tissue chamber by an agar tube. Both the microelectrode and the reference electrode were connected to the microelectrode amplifier (Biomedical Instruments, München, Germany), which measured the electric voltage between both electrodes. Additionally, the microelectrode amplifier was connected to an oscilloscope (DSO 420; Gould, Ilford, UK), which presented the electrical changes in the membrane potential. A paper recorder (BD 41; Kipp \& Zonen BV, Delft, the Netherlands) plotted these data. The smooth muscle cells were punctured under electrical control: successful measurement was characterized by an abrupt voltage drop to at least $-20 \mathrm{mV}$ over $1 \mathrm{~min}$. Thereafter, plotting with the paper recorder started. 
All microelectrode experiments were performed in the presence of $1 \mu M$ nifedipine diluted in the buffer solutions. Nifedipine inhibits L-type calcium channels without having an effect on the slow wave activity (Suzuki and Hirst, 1999). It was necessary to repress the contraction of the smooth muscle cells during microelectrode measurements, because previous experiments had shown (data not shown), that constant measurements were impossible as long as smooth muscles cells contracted.

Experimental Design. The tissues from 23 bulls were assigned to 2 groups: the muscle strips of group 1 were treated with $\mathrm{KH}$ buffer with a total calcium concentration of $1.2 \mathrm{mmol}$ of $\mathrm{CaCl}_{2} / \mathrm{L}$ (subclinical hypocalcemia); those of group 2 were treated with $\mathrm{KH}$ buffer with a total calcium concentration of $2.4 \mathrm{mmol}$ of $\mathrm{CaCl}_{2} / \mathrm{L}$ (normocalcemia, reference range: 2.1-2.8 $\mathrm{mmol} / \mathrm{L}$ ). The concentration of ionized $\mathrm{Ca}$ as determined by ion-selective electrodes amounted to 1.71 $\mathrm{mmol} / \mathrm{L}$ in the normocalcemic and to $0.91 \mathrm{mmol} / \mathrm{L}$ in the hypocalcemic buffer solution. Tissue samples of 5 and 4 bulls were used as time control under subclinical hypocalcemic and normocalcemic conditions, respectively. The effect of BHBA was tested on samples from 6 bulls under subclinical hypocalcemic conditions and on samples from 5 bulls under normocalcemic conditions. Additionally, the effect of the $\mathrm{K}$ channel blocker barium chloride $\left(2 \mathrm{mmol}\right.$ of $\mathrm{BaCl}_{2} / \mathrm{L}$ ) was tested on samples from 5 bulls in low-Ca buffer. The microelectrode procedure followed the pattern described in Table 1. Tissues from the 5 cows were incubated in low-Ca buffer and treated with $5 \mathrm{mmol}$ of BHBA/L.

Evaluation. Changes of the membrane potentials were determined by evaluating the basal membrane potential $(\mathrm{mV})$, the frequency of depolarizations $(1 / \mathrm{min})$, and the height of the amplitudes $\geq 3 \mathrm{mV}$ and $\geq 5 \mathrm{mV}$ for every 5-min measuring interval. Statistical analysis was performed with the program GraphPad Prism 4.0 (GraphPad Software, La Jolla, CA). The effect of the treatment was assessed by a paired and 2-tailed $t$-test. The unpaired 2 -tailed $t$-test was used to compare treated with nontreated smooth muscle cells.

\section{In Vitro Motility Measurements}

Smooth muscle strips were prepared as previously described by Guschlbauer et al. (2010). Briefly, mucosa and submucosa were removed and commensurate strips $(0.5 \times 1 \mathrm{~cm})$ of the circular smooth muscle were prepared. Each strip was mounted into an organ bath $(8$ chambers) filled with $12 \mathrm{~mL}$ of Krebs-Henseleit buffer $\left(37^{\circ} \mathrm{C}\right)$ and fitted with an isometric force transducer. The initial tension of muscle strips was adjusted between 10 and $110 \mathrm{mN}$ and they were equilibrated for 60 to $90 \mathrm{~min}$. Isometric contractile forces of smooth muscle samples were measured with a Spider 8 chart recorder $(4.8 \mathrm{kHz} / \mathrm{DC}$; Hottinger Baldwin Messtechnik, Darmstadt, Germany). Data were collected with Catman Easy software (version 1.01; Hottinger Baldwin Messtechnik). Contractile activity was determined by measuring the average amplitude of contraction $(\mathrm{mN})$, the frequency of contractions $(1 / \mathrm{min})$, the average force of the contraction $(\mathrm{mN})$, and the activity of contraction $(\mathrm{mN} / \mathrm{min})$.

Experimental Design. Tissues from all animals (n $=10$ ) were treated with $5 \mathrm{mmol}$ of BHBA/L under low$\mathrm{Ca}$ conditions; addition of an equimolar $\mathrm{NaCl}$ solution served as control treatment. The identical procedure was repeated on the day after slaughtering with 7 of the 10 bulls. In the continuous presence of BHBA or $\mathrm{NaCl}$, additionally, half of the tissues received an additional $1.2 \mathrm{mmol}$ of $\mathrm{CaCl}_{2} / \mathrm{L}$, which doubled the calcium concentration to $2.4 \mathrm{mmol}$ of $\mathrm{CaCl}_{2} / \mathrm{L}$ ( 8 animals). Seven bulls were treated identically on the second day. Different potassium concentrations in the buffer were tested on 4 animals at $2 \mathrm{~d}$. For these measurements, the buffer was changed from a solution containing $5.4 \mathrm{mmol}$ of $\mathrm{KCl} / \mathrm{L}$ to a buffer with $2 \mathrm{mmol}$ of $\mathrm{KCl} / \mathrm{L}$, which was followed by addition of $1 \mathrm{mmol}$ of $\mathrm{KCl} / \mathrm{L}$ to a total of $3 \mathrm{mmol}$ of $\mathrm{KCl} / \mathrm{L}$ in buffer solution (Table 2). The muscles strips were weighted after the experiment to evaluate a possible correlation between the weight and the force of the contraction.

Evaluation. Data collected in the motility experiments were not distributed normally according to

Table 1. Experimental design of the microelectrode experiments

\begin{tabular}{|c|c|c|c|c|}
\hline \multirow[b]{2}{*}{ Minute } & \multirow[b]{2}{*}{ Evaluation } & \multicolumn{3}{|c|}{ Treatment } \\
\hline & & Time control & BHBA & $\mathrm{BaCl}_{2}$ \\
\hline 1 to 5 & Interval 1 & KH buffer ${ }^{1}$ & KH buffer & KH buffer \\
\hline 6 to 7 & & & Buffer change & Buffer change \\
\hline 8 to 12 & Interval 2 & KH buffer & $\mathrm{KH}$ buffer + BHBA & $\mathrm{KH}$ buffer $+\mathrm{BaCl}_{2}$ \\
\hline 13 to 14 & & & Buffer change & Buffer change \\
\hline 15 to 19 & Interval 3 & KH buffer & KH buffer & KH buffer \\
\hline
\end{tabular}

${ }^{1} \mathrm{KH}$ buffer $=$ Krebs-Henseleit buffer. 
Table 2. Experimental design of the in vitro motility measurements

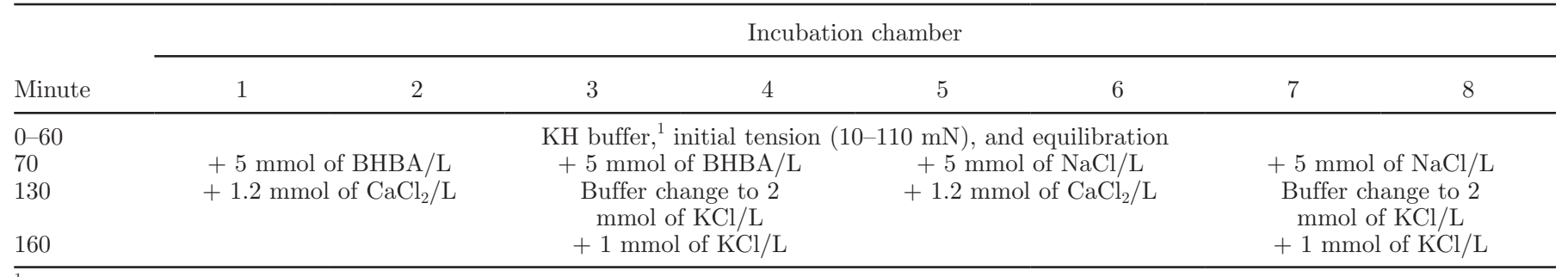

${ }^{1} \mathrm{KH}$ buffer $=$ Krebs-Henseleit buffer.

analysis by the Kolmogorov-Smirnov test. Therefore, medians with minima and maxima were used to present the parameters. Medians were compared with the Wilcoxon signed-rank test. A value of $P<0.05$ was regarded as significant.

\section{RESULTS}

\section{Microelectrode Measurements}

General Considerations. The microelectrode measurements showed a wide range of variation in the frequency of the slow waves and the height of their amplitudes. The subdivision into amplitudes $\geq 3$ and $\geq 5 \mathrm{mV}$ was applied as an attempt to differentiate the contraction promoting slow waves from a ubiquitous background noise. It was possible to work $2 \mathrm{~d}$ with the tissue samples and to analyze the first and second day together, because no statistical differences existed between both days (data not shown).

Time Controls. Tissue samples incubated in low-Ca buffer showed stable parameters over time, except for the frequency of amplitudes $\geq 5 \mathrm{mV}$, which decreased from interval 1 to 2 (Table 3 ). The abomasal smooth muscle cells incubated in normocalcemic buffer also showed changes $(P<0.05)$ in the frequency of the amplitudes $\geq 5 \mathrm{mV}$ (Table 4). No other time effects on the evaluated characteristics were observed (Table 4). Tissues from cows with LDA showed no significant variations during time control (Table 5). The membrane potential was on a similar level as the bull samples under hypocalcemic conditions. The frequencies of the amplitudes were considerably higher than in the tissues from bulls.

BHBA Treatment. In bulls and under hypocalcemic conditions, the treatment with BHBA $(5 \mathrm{mmol} / \mathrm{L})$ had no effect (reported as means \pm SEM) on the basal membrane potential, the frequency of the amplitudes $\geq 3$ and $\geq 5 \mathrm{mV}$, and the height of the amplitudes $\geq 5 \mathrm{mV}$. The average height of the amplitudes $\geq 3 \mathrm{mV}$ decreased under BHBA (Table 6). This effect was not reversible after buffer change. The BHBA-induced decrease in amplitude $(-0.8 \pm 0.3 \mathrm{mV}$; Table 6$)$ was, however, not different from the time-dependent change $(-0.2 \pm 0.1$ $\mathrm{mV}$; Table 3). In tissues from bulls incubated under normocalcemic conditions, the treatment with BHBA showed no effect on any evaluated parameter (Table 7). The frequency of amplitudes $\geq 5 \mathrm{mV}$ showed a nominal decrease with time (Tables 6 and 7) as was observed in the absence of BHBA (Tables 3 and 4). In tissues from cows with LDA that had been incubated under hypocalcemic conditions, BHBA tended to decrease the height of the amplitudes $\geq 3 \mathrm{mV}(P<0.1)$ by $0.5 \pm 0.2$ $\mathrm{mV}$ (Table 8). This was, however, not different from the time-dependent decrease of $0.4 \pm 0.3 \mathrm{mV}$ (Table $5)$. Likewise, the decrease in frequency of amplitudes $\geq 5 \mathrm{mV}(2.4 \pm 1.1 / \mathrm{min}$; Table 8$)$ was not different from the time-dependent decrease $(0.7 \pm 0.5 / \mathrm{min}$; Table 5$)$.

Treatment with Barium Chloride. Addition of 2 mmol of $\mathrm{BaCl}_{2} / \mathrm{L}$ induced a depolarization of the mem-

Table 3. Changes in the membrane potential (means \pm SEM; $n=5$ ) of abomasal smooth muscle cells from bulls during time controlled, hypocalcemic conditions $\left(1.2 \mathrm{mmol}\right.$ of $\left.\mathrm{CaCl}_{2} / \mathrm{L}\right)$

\begin{tabular}{lccc}
\hline Item & Interval 1 $(\min 1-5)$ & Interval 2 (min 8-12) & Interval 3 (min 15-19) \\
\hline Basal membrane potential, $\mathrm{mV}$ & $-37.0 \pm 3.0$ & $-37.8 \pm 4.0$ & $-37.2 \pm 4.8$ \\
Amplitude $\geq 3 \mathrm{mV}$ & $5.6 \pm 1.4$ & $4.8 \pm 1.3$ & $4.4 \pm 1.0$ \\
Frequency, 1/min & $4.4 \pm 0.2$ & $4.2 \pm 0.2$ & $4.5 \pm 0.5$ \\
Height, $\mathrm{mV}$ & & $1.6 \pm 0.7^{\mathrm{b}}$ & $1.4 \pm 0.6^{\mathrm{b}}$ \\
Amplitude $\geq 5 \mathrm{mV}$ & $2.2 \pm 0.8^{\mathrm{a}}$ & $6.1 \pm 0.3$ & $6.7 \pm 0.8$ \\
Frequency, 1/min & $6.4 \pm 0.5$ & \\
Height, $\mathrm{mV}$ &
\end{tabular}

${ }^{\mathrm{a}, \mathrm{b}}$ Means within a row with different superscripts differ $(P<0.05)$. 
Table 4. Changes in the membrane potential (means $\pm \mathrm{SEM} ; \mathrm{n}=4$ ) of abomasal smooth muscle cells from bulls during time controlled, normocalcemic conditions $\left(2.4 \mathrm{mmol}\right.$ of $\left.\mathrm{CaCl}_{2} / \mathrm{L}\right)$

\begin{tabular}{lccc}
\hline Item & Interval $1(\min 1-5)$ & Interval 2 (min 8-12) & Interval 3 (min 15-19) \\
\hline Basal membrane potential, $\mathrm{mV}$ & $-49.8 \pm 2.9$ & $-49.0 \pm 3.7$ & $-47.0 \pm 3.4$ \\
Amplitude $\geq 3 \mathrm{mV}$ & & $3.5 \pm 1.1$ & $4.8 \pm 0.9$ \\
Frequency, $1 / \mathrm{min}$ & $4.5 \pm 0.6$ & $4.0 \pm 0.4$ & $4.3 \pm 0.4$ \\
Height, $\mathrm{mV}$ & $4.4 \pm 0.6$ & $0.6 \pm 0.3^{\mathrm{b}}$ & $1.5 \pm 0.5^{\mathrm{ab}}$ \\
Amplitude $\geq 5 \mathrm{mV}$ & $1.1 \pm 0.3^{\mathrm{a}}$ & $6.2 \pm 1.0$ & $6.3 \pm 0.5$ \\
Frequency, $1 / \mathrm{min}$ & $6.0 \pm 0.7$ & \\
Height, $\mathrm{mV}$ &
\end{tabular}

${ }^{\mathrm{a}, \mathrm{b}}$ Means within a row with different superscripts differ $(P<0.05)$.

Table 5. Changes in the membrane potential (means \pm SEM; $n=4$ ) of abomasal smooth muscle cells from cows with left displacement of the abomasum (LDA) during time control, hypocalcemic conditions $\left(1.2 \mathrm{mmol}\right.$ of $\left.\mathrm{CaCl}_{2} / \mathrm{L}\right)$

\begin{tabular}{lccc}
\hline Item & Interval 1 (min 1-5) & Interval 2 (min 8-12) & Interval 3 (min 15-19) \\
\hline Basal membrane potential, $\mathrm{mV}$ & $-37.5 \pm 4.8$ & $-38.3 \pm 4.7$ & $-40.5 \pm 4.8$ \\
Amplitude $\geq 3 \mathrm{mV}$ & & & \\
Frequency, 1/min & $10.5 \pm 1.9$ & $10.5 \pm 2.1$ & $8.9 \pm 1.4$ \\
Height, $\mathrm{mV}$ & $4.7 \pm 0.7$ & $4.3 \pm 0.4$ & $4.1 \pm 0.2$ \\
Amplitude $\geq 5 \mathrm{mV}$ & & $3.8 \pm 1.3$ & $2.5 \pm 0.5$ \\
Frequency, 1/min & $4.5 \pm 1.8$ & $5.9 \pm 0.4$ & $6.1 \pm 0.3$ \\
Height, $\mathrm{mV}$ & $6.2 \pm 0.7$ & & \\
\hline
\end{tabular}

Table 6. Changes in the membrane potential (means \pm SEM; $n=6$ ) of abomasal smooth muscle cells from bulls under the effect of BHBA $(5 \mathrm{mmol} / \mathrm{L})$ under hypocalcemic conditions $\left(1.2 \mathrm{mmol}\right.$ of $\left.\mathrm{CaCl}_{2} / \mathrm{L}\right)$

\begin{tabular}{|c|c|c|c|}
\hline \multirow[b]{2}{*}{ Item } & Interval 1 & Interval 2 & Interval 3 \\
\hline & KH buffer ${ }^{1}$ & + BHBA & KH buffer \\
\hline \multirow{2}{*}{\multicolumn{4}{|c|}{ Amplitude $\geq 3 \mathrm{mV}$}} \\
\hline & & & \\
\hline Frequency, $1 / \min$ & $4.7 \pm 0.5$ & $4.8 \pm 0.6$ & $4.6 \pm 0.7$ \\
\hline Height, $\mathrm{mV}$ & $5.1 \pm 0.4^{\mathrm{a}}$ & $4.3 \pm 0.3^{\mathrm{b}}$ & $4.3 \pm 0.4^{\mathrm{ab}}$ \\
\hline \multicolumn{4}{|l|}{ Amplitude $\geq 5 \mathrm{mV}$} \\
\hline Frequency, $1 / \min$ & $2.3 \pm 0.5$ & $1.4 \pm 0.5$ & $1.4 \pm 0.4$ \\
\hline Height, mV & $6.5 \pm 0.4$ & $6.2 \pm 0.5$ & $6.2 \pm 0.5$ \\
\hline
\end{tabular}

a,b Means within a row with different superscripts differ $(P<0.05)$.

${ }^{1} \mathrm{KH}$ buffer $=$ Krebs-Henseleit buffer.

Table 7. Changes in the membrane potential (means \pm SEM; $n=5$ ) of abomasal smooth muscle cells from bulls under the effect of BHBA $(5 \mathrm{mmol} / \mathrm{L})$ under normocalcemic conditions $\left(2.4 \mathrm{mmol}\right.$ of $\left.\mathrm{CaCl}_{2} / \mathrm{L}\right)$

\begin{tabular}{|c|c|c|c|}
\hline & Interval 1 & Interval 2 & Interval 3 \\
\hline Item & KH buffer ${ }^{1}$ & $+\mathrm{BHBA}$ & KH buffer \\
\hline Basal membrane potential, $\mathrm{mV}$ & $-40.0 \pm 2.8$ & $-34.2 \pm 3.0$ & $-35.8 \pm 3.4$ \\
\hline \multicolumn{4}{|l|}{ Amplitude $\geq 3 \mathrm{mV}$} \\
\hline Frequency, $1 / \min$ & $5.9 \pm 1.5$ & $4.6 \pm 0.5$ & $2.4 \pm 0.5$ \\
\hline Height, mV & $4.8 \pm 0.6$ & $4.2 \pm 0.3$ & $3.7 \pm 0.5$ \\
\hline \multicolumn{4}{|l|}{ Amplitude $\geq 5 \mathrm{mV}$} \\
\hline Frequency, 1/min & $1.8 \pm 0.5$ & $1.2 \pm 0.4$ & $0.5 \pm 0.4$ \\
\hline Height, mV & $7.0 \pm 1.0$ & $6.1 \pm 0.3$ & $7.1 \pm 0.6$ \\
\hline
\end{tabular}

${ }^{1} \mathrm{KH}$ buffer $=$ Krebs-Henseleit buffer. 
Table 8. Changes in the membrane potential (means \pm SEM; $n=5$ ) of abomasal smooth muscle cells from cows with left displacement of the abomasum (LDA) under the effect of BHBA ( $5 \mathrm{mmol} / \mathrm{L})$ under hypocalcemic conditions $\left(1.2 \mathrm{mmol}\right.$ of $\left.\mathrm{CaCl}_{2} / \mathrm{L}\right)$

\begin{tabular}{|c|c|c|c|}
\hline & Interval 1 & Interval 2 & Interval 3 \\
\hline Item & KH buffer ${ }^{1}$ & $+\mathrm{BHBA}$ & KH buffer \\
\hline $\begin{array}{l}\text { Basal membrane potential, } \mathrm{mV} \\
\text { Amplitude }>3 \mathrm{mV}\end{array}$ & $-41.6 \pm 5.7$ & $-40.8 \pm 4.3$ & $-38.8 \pm 5.6$ \\
\hline Frequency, $1 / \mathrm{min}$ & $10.9 \pm 2.1$ & $7.4 \pm 2.1$ & $6.8 \pm 2.6$ \\
\hline Height, $\mathrm{mV}$ & $4.4 \pm 0.2$ & $3.9 \pm 0.3$ & $4.3 \pm 0.7$ \\
\hline Amplitude $\geq 5 \mathrm{mV}$ & & & \\
\hline Frequency, $1 / \mathrm{min}$ & $4.4 \pm 1.1$ & $2.0 \pm 1.3$ & $2.6 \pm 2.2$ \\
\hline Height, mV & $5.8 \pm 0.2$ & $5.7 \pm 0.4$ & $6.4 \pm 0.8$ \\
\hline
\end{tabular}

${ }^{1} \mathrm{KH}$ buffer $=$ Krebs-Henseleit buffer.

brane potential by about $6 \mathrm{mV} \pm 1.8$ (mean $\pm \mathrm{SEM}$; $P<0.05)$. This effect was reversible after washout $(P$ $<0.05)$. The frequencies and heights of the amplitudes were not modified by $\mathrm{BaCl}_{2}$ (Table 9 ).

\section{Motility Experiments}

BHBA Treatment. Because no effect was observed on contraction parameters between $\mathrm{d} 1$ and 2 , the experimental days were averaged per animal, so the tables show the average of all animals in the study. Time had no effect on the amplitude of contraction and the frequency and the activity of contraction. The average force of the tissues decreased in controls over time from 10.4 to $9.0 \mathrm{mN}(P<0.05$; Table 10$)$ and in BHBA-treated tissues from 12.0 to $9.5 \mathrm{mN}(P<0.05$; Table 11). The effects seen under BHBA treatment did not differ from time control. This was also true for the changes observed in the frequency of contraction (Tables 10 and 11).

Calcium Addition to Obtain Normocalcemic Conditions. The addition of $1.2 \mathrm{mmol}$ of $\mathrm{CaCl}_{2} / \mathrm{L}$ raised the total calcium concentration in the buffer solution up to the normocalcemic level $(2.4 \mathrm{mmol}$ of
$\left.\mathrm{CaCl}_{2} / \mathrm{L}\right)$. $\quad \beta$-Hydroxybutyrate-treated tissue samples and control samples were evaluated separately. Both the control muscle strips and the BHBA-treated strips showed no effect of an increased calcium concentration (see Tables 12 and 13).

Different Potassium Concentrations. In testing the effect of different potassium concentrations on the contractility of abomasal muscle strips, BHBA-treated and control tissues were evaluated separately. In both groups, the average amplitude and the activity of contraction decreased nominally when reducing potassium concentration from 5.4 to $2 \mathrm{mmol}$ of KCL/L. The addition of $1 \mathrm{mmol}$ of KCL/L induced a nominal increase of the mean amplitude of contraction. These effects failed, however, to reach significance (Tables 14 and 15). The average force decreased again over time in all muscle strips.

Does a Correlation Exist Between the Weight and the Force of Contraction? A possible relationship between the weight of the muscle strips and the force of contraction was tested with linear regression on a total of 123 muscle strips from 10 animals. No relation existed between these parameters $\left[\mathrm{R}^{2}=0.0069\right.$, slope $( \pm \mathrm{SD}): 29.29 \pm 31.98]$.

Table 9. Changes in the membrane potential (means \pm SEM; $n=5$ ) of abomasal smooth muscle cells from bulls under the effect of $\mathrm{BaCl}_{2}(2 \mathrm{mmol} / \mathrm{L})$ under hypocalcemic conditions $\left(1.2 \mathrm{mmol}\right.$ of $\left.\mathrm{CaCl}_{2} / \mathrm{L}\right)$

\begin{tabular}{|c|c|c|c|}
\hline & Interval 1 & Interval 2 & Interval 3 \\
\hline Item & KH buffer $^{1}$ & $+\mathrm{BaCl}_{2}$ & KH buffer \\
\hline $\begin{array}{l}\text { Basal membrane potential, } \mathrm{mV} \\
\text { Amplitude }>3 \mathrm{mV}\end{array}$ & $-43.0 \pm 2.9^{\mathrm{a}}$ & $-37.0 \pm 4.1^{\mathrm{b}}$ & $-41.8 \pm 3.1^{\mathrm{a}}$ \\
\hline Frequency, $1 / \mathrm{min}$ & $6.1 \pm 0.7$ & $6.3 \pm 1.1$ & $7.1 \pm 2.1$ \\
\hline Height, $\mathrm{mV}$ & $5.3 \pm 0.4$ & $7.6 \pm 2.3$ & $5.2 \pm 0.6$ \\
\hline $\begin{array}{l}\text { Amplitude } \geq 5 \mathrm{mV} \\
\text { Frequency, } 1 / \mathrm{min}\end{array}$ & $3.0 \pm 0.4$ & $3.4 \pm 0.4$ & $2.8 \pm 1.0$ \\
\hline Height, $\mathrm{mV}$ & $6.7 \pm 0.2$ & $9.7 \pm 3.0$ & $7.9 \pm 1.8$ \\
\hline
\end{tabular}

${ }^{\mathrm{a}, \mathrm{b}}$ Means within a row with different superscripts differ $(P<0.05)$.

${ }^{1} \mathrm{KH}$ buffer = Krebs-Henseleit buffer. 
Table 10. Changes in motility (medians, with minima; maxima in parentheses; $\mathrm{n}=10$ ) of abomasal smooth muscles from bulls with time and under hypocalcemic conditions $\left(1.2 \mathrm{mmol}\right.$ of $\left.\mathrm{CaCl}_{2} / \mathrm{L}\right)$

\begin{tabular}{|c|c|c|c|c|}
\hline Item & $\begin{array}{c}\text { Amplitude of } \\
\text { contraction, } \mathrm{mN}\end{array}$ & $\begin{array}{c}\text { Frequency of } \\
\text { contraction, } 1 / \min \end{array}$ & Average force, $\mathrm{mN}$ & $\begin{array}{c}\text { Activity of } \\
\text { contraction, } \mathrm{mN} / \mathrm{min}\end{array}$ \\
\hline 5 min before $\mathrm{NaCl}^{1}$ addition & $7.2(1.3 ; 28.3)$ & $1.9(0.3 ; 5.1)$ & $10.4^{\mathrm{a}}(2.2 ; 23.7)$ & $14.5(0.4 ; 56.5)$ \\
\hline 5 min after $\mathrm{NaCl}$ addition & $7.3(4.0 ; 28.9)$ & $2.1(0.6 ; 5.1)$ & $10.3^{\mathrm{ab}}(3.6 ; 19.9)$ & $14.2(3.3 ; 65.1)$ \\
\hline 40 min after $\mathrm{NaCl}$ addition & $6.5(4.6 ; 33.4)$ & $2.0(1.4 ; 4.1)$ & $9.0^{\mathrm{b}}(2.4 ; 20.6)$ & $14.2(8.9 ; 68.6)$ \\
\hline
\end{tabular}

$\overline{\mathrm{a}, \mathrm{b}}$ Means within a column with different superscripts differ $(P<0.05)$.

${ }^{1} \mathrm{NaCl}(5 \mathrm{mmol} / \mathrm{L})$ was added as osmotic time control for the BHBA experiment (Table 11).

Table 11. Changes in motility (medians, with minima; maxima in parentheses; $n=10$ ) of abomasal smooth muscles from bulls under the effect of $\operatorname{BHBA}(5 \mathrm{mmol} / \mathrm{L})$ and under hypocalcemic conditions $\left(1.2 \mathrm{mmol}\right.$ of $\left.\mathrm{CaCl}_{2} / \mathrm{L}\right)$

\begin{tabular}{lccrr}
\hline Item & $\begin{array}{c}\text { Amplitude of } \\
\text { contraction, } \mathrm{mN}\end{array}$ & $\begin{array}{c}\text { Frequency of } \\
\text { contraction, } 1 / \mathrm{min}\end{array}$ & $\begin{array}{c}\text { Activity of } \\
\text { Average force, } \mathrm{mN}\end{array}$ & $\begin{array}{c}\text { contraction, mN } / \mathrm{min} \\
5 \text { min before BHBA addition }\end{array}$ \\
5 min after BHBA addition & $6.5(1.5 ; 44.7)$ & $1.8^{\mathrm{a}}(0.9 ; 6.5)$ & $12.0^{\mathrm{a}}(3.8 ; 23.2)$ & $13.3(2.6 ; 98.2)$ \\
40 min after BHBA addition & $7.8(4.1 ; 38.6)$ & $2.0^{\mathrm{b}}(1.0 ; 6.8)$ & $11.5^{\mathrm{b}}(2,4 ; 19.1)$ & $14.7(5.2 ; 88.9)$ \\
\hline
\end{tabular}

$\overline{\mathrm{a}, \mathrm{b}}$ Means within a column with different superscripts differ $(P<0.05)$.

Table 12. Effect of calcium on the motility (medians, with minima; maxima in parentheses; $\mathrm{n}=8$ ) of abomasal smooth muscles from bulls

\begin{tabular}{lcccr}
\hline Item & $\begin{array}{c}\text { Amplitude of } \\
\text { contraction, mN }\end{array}$ & $\begin{array}{c}\text { Frequency of } \\
\text { contraction, } 1 / \text { min }\end{array}$ & Average force, mN & $\begin{array}{c}\text { Activity of } \\
\text { contraction, mN/min }\end{array}$ \\
\hline $1.2 \mathrm{mmol}$ of $\mathrm{Ca} / \mathrm{L}^{1}$ & $6.5(3.7 ; 12.4)$ & $2.1(0.6 ; 3.5)$ & $8.2(4.0 ; 15.4)$ & $15.3(2.3 ; 43.6)$ \\
5 min with $2.4 \mathrm{mmol}$ of $\mathrm{Ca} / \mathrm{L}$ & $6.0(1.5 ; 12.0)$ & $3.1(0.2 ; 3.7)$ & $6.8(3.2 ; 12.1)$ & $18.3(0.3 ; 44.2)$ \\
40 min with $2.4 \mathrm{mmol}$ of $\mathrm{Ca} / \mathrm{L}$ & $5.5(4.9 ; 9.2)$ & $2.6(1.3 ; 4.0)$ & $4.4(2.2 ; 24.0)$ & $13.5(6.8 ; 36.4)$ \\
\hline
\end{tabular}

${ }^{1}$ Parameters measured 5 min before the Ca concentration was increased.

Table 13. Effect of calcium on the motility (medians, with minima; maxima in parentheses; $n=8$ ) of abomasal smooth muscles from bulls in the presence of BHBA $(5 \mathrm{mmol} / \mathrm{L})$

\begin{tabular}{lcccc}
\hline Item & $\begin{array}{c}\text { Amplitude of } \\
\text { contraction, mN }\end{array}$ & $\begin{array}{c}\text { Frequency of } \\
\text { contraction, } 1 / \text { min }\end{array}$ & Average force, mN & $\begin{array}{c}\text { Activity of } \\
\text { contraction, mN/min }\end{array}$ \\
\hline $1.2 \mathrm{mmol}$ of $\mathrm{Ca} / \mathrm{L}^{1}$ & $6.8(3.3 ; 7.8)$ & $2.3(1.0 ; 4.9)$ & $8.9(3.7 ; 15.3)$ & $17.7(4.8 ; 33.8)$ \\
$5 \mathrm{~min}$ with $2.4 \mathrm{mmol}$ of $\mathrm{Ca} / \mathrm{L}$ & $6.7(3.1 ; 10.1)$ & $2.7(0.6 ; 5.1)$ & $7.7(3.9 ; 14.0)$ & $20.2(3.1 ; 44.6)$ \\
40 min with $2.4 \mathrm{mmol}$ of $\mathrm{Ca} / \mathrm{L}$ & $7.0(4.1 ; 11.6)$ & $2.6(0.6 ; 4.4)$ & $5.2(1.6 ; 20.6)$ & $17.1(2.5 ; 50.3)$ \\
\hline
\end{tabular}

${ }^{1}$ Parameters measured 5 min before the Ca concentration was increased.

Table 14. Effect of potassium on the motility (medians, with minima; maxima in parentheses; $\mathrm{n}=4$ ) of abomasal smooth muscles from bulls under hypocalcemic conditions

\begin{tabular}{lcccc}
\hline Item & $\begin{array}{c}\text { Amplitude of } \\
\text { contraction, mN }\end{array}$ & $\begin{array}{c}\text { Frequency of } \\
\text { contraction, } 1 / \text { min }\end{array}$ & Average force, mN & $\begin{array}{c}\text { Activity of } \\
\text { contraction, mN/min }\end{array}$ \\
\hline $5.4 \mathrm{mmol}$ of $\mathrm{K} / \mathrm{L}$ & $8.3(5.7 ; 13.3)$ & $2.9(1.1 ; 3.8)$ & $17.7(13.0 ; 21.6)$ & $22.2(8.4 ; 50.4)$ \\
$2.0 \mathrm{mmol}$ of $\mathrm{L} / \mathrm{L}$ & $5.5(1.4 ; 7.0)$ & $2.9(0.7 ; 5.5)$ & $14.6(6.1 ; 17.5)$ & $18.6(0.9 ; 29.7)$ \\
$3.0 \mathrm{mmol}$ of $\mathrm{L}$ & $9.1(6.2 ; 22.0)$ & $2.7(1.7 ; 3.2)$ & $10.1(2.8 ; 22.7)$ & $25.7(10.3 ; 67)$ \\
\hline
\end{tabular}

Table 15. Effect of potassium on the motility (medians, with minima; maxima in parentheses; $\mathrm{n}=4$ ) of abomasal smooth muscles from bulls after incubation with BHBA (5 mmol/L) and under hypocalcemic conditions

\begin{tabular}{lcccc}
\hline Item & $\begin{array}{c}\text { Amplitude of } \\
\text { contraction, mN }\end{array}$ & $\begin{array}{c}\text { Frequency of } \\
\text { contraction, } 1 / \text { min }\end{array}$ & Average force, mN & $\begin{array}{c}\text { Activity of } \\
\text { contraction, mN/min }\end{array}$ \\
\hline $5.4 \mathrm{mmol}$ of $\mathrm{K} / \mathrm{L}$ & $12.5(5.1 ; 14.8)$ & $2.0(0.7 ; 3.5)$ & $11.8(10.7 ; 18.7)$ & $15.4(10.4 ; 50.1)$ \\
$2.0 \mathrm{mmol}$ of $\mathrm{L}$ & $5.3(3.3 ; 7.8)$ & $1.8(0.2 ; 6.0)$ & $6.1(5.1 ; 10.2)$ & $12.4(0.5 ; 30.1)$ \\
$3.0 \mathrm{mmol}$ of $\mathrm{L} / \mathrm{L}$ & $8.6(3.3 ; 21.8)$ & $2.2(1.3 ; 3.7)$ & $8.9(2.4 ; 17.6)$ & $19.2(4.1 ; 80.7)$ \\
\hline
\end{tabular}




\section{DISCUSSION}

\section{Slow Waves and Motility of Abomasal Smooth Muscle Cells}

To our knowledge, no studies on microelectrode measurements of abomasal slow waves have been published up to now. The conducted subdivision of the height of the amplitudes in $\geq 3$ and $\geq 5 \mathrm{mV}$ was based on the wide range of variation. It was an attempt to demarcate the slow waves from ubiquitous background noise. The other evaluated parameters, basal membrane potential and frequency of amplitudes $\geq 3$ and $\geq 5 \mathrm{mV}$, showed a wide distribution as well. Intracellular recordings of gastric corporal slow waves of guinea pigs presented similar wide distributions. The height of those amplitudes ranged from 5.3 to $26.8 \mathrm{mV}$, the basal membrane potential was between -44 and $-56 \mathrm{mV}$, and the frequency was between 4.9 and 5.1 per minute (Hashitani et al., 2005).

In our study, the frequency of slow waves (amplitudes $\geq 3 \mathrm{mV}$ ) under normocalcemic conditions ranged from 3.5 to 4.8 per minute, whereas the frequencies of slow waves with amplitudes $\geq 5 \mathrm{mV}$ ranged from 0.6 to 1.5 per minute. The frequencies of contraction observed in our study under normocalcemic conditions ranged from 2.6 to 3.1 per minute. These frequencies were between those of the 2 slow wave classes, but are in the same order as previous motility studies: in vitro motility experiments under similar buffer solutions have shown contraction frequencies of 2.9 per minute (Geishauser et al., 1998) and 3 to 4 per minute (Türck and Leonhard-Marek, 2010); the abomasal contraction activity measured in vivo in cattle amounted to 2.3 per minute (Daniel, 1983).

When comparing microelectrode with motility results, the following factors have to be regarded. During the recording of membrane potentials with microelectrodes only a single smooth muscle cell is registered. The influence of neighboring ICC and their effect on the slow waves depends on the distance of electric coupling between the cells. In vitro motility experiments, by contrast, capture the activity of many smooth muscle cells. That means, if not every single muscle cell contracts, it is still possible to measure contractions of the whole muscle strip. At the same time, several pacemaker potentials can superimpose and result in 1 contraction.

Additionally, the temperature can affect the frequency of slow waves as well. In a range between 26 and $40^{\circ} \mathrm{C}$, the frequency of pacemaker potentials in ICC of the mouse small intestine increased linearly with the temperature of the buffer solution (Kito and Suzuki, 2007). It is very likely that this temperature effect can be transferred to the slow wave frequency because the pacemaker potentials represent the origin of the slow waves. Extrapolating the frequency of the slow waves measured at room temperature $\left(21^{\circ} \mathrm{C}\right)$ in our microelectrode experiments with the correlations observed by Kito and Suzuki (2007), would result in frequencies of about 1.5 to 3.8 per minute for slow waves with amplitudes $\geq 5 \mathrm{mV}$ (at $37^{\circ} \mathrm{C}$ ). This is in perfect agreement with the frequencies of abomasal contractions observed both in vitro and in vivo at the same temperature (Daniel, 1983; Geishauser et al., 1998; Türck and Leonhard-Marek, 2010). The microelectrode technique thus seems an adequate method to define slow waves in the abomasum, and a change in membrane potential $\geq 5 \mathrm{mV}$ (in this case, slow waves with amplitudes $\geq 5$ $\mathrm{mV}$ ) seems to correlate with contractions of abomasal muscles.

\section{Effect of Potassium on Membrane Potential and Motility of Abomasal Smooth Muscle Cells}

Due to the activity of the ubiquitous $\mathrm{Na} / \mathrm{K}$ pump, the $\mathrm{K}$ concentration inside cells generally by far exceeds the extracellular K concentration. Diffusion of K ions along this concentration gradient is then responsible for the generation of a potential difference across the cell membrane, which leaves the cell with an inside negative membrane potential. Barium, as a nonselective potassium channel blocker, inhibits $\mathrm{K}$ efflux. In line with this relation, our treatment with $\mathrm{BaCl}_{2}$ induced a depolarization of the basal membrane potential by about $6 \mathrm{mV}$ (Table 9) without affecting the frequency or the amplitudes of the slow waves. Vanheel and Breyne (2004) likewise showed that barium depolarized the membrane potential of cells from small gastric arteries of rats. They recorded a depolarization of 5 $\mathrm{mV}$ after treatment with $30 \mu \mathrm{mol}$ of barium/L using conventional microelectrode techniques.

As changes in membrane potential with amplitudes $\geq 5 \mathrm{mV}$ correlated with an increased contraction activity (see above), an addition of barium should also increase the contraction of abomasal muscles. This is indeed the case, as shown in previous experiments of our group (Türck and Leonhard-Marek, 2010).

In reducing $\mathrm{K}$ efflux from the cells, barium imitates hyperkalemic conditions, which result in less negative membrane potentials as well. Thereby, the threshold potential of potential dependent calcium channels can be reached faster and longer, which should result in a longer and stronger contraction of the smooth muscle cell. This theory could be confirmed in different studies. Smooth muscle cells of canine small intestine showed a depolarization of the membrane potential when exposed to an increased extracellular potassium 
concentration (Hara and Szurszewski, 1986). In uterine smooth muscle cells of rats, a gradual increase of the extracellular potassium concentration likewise resulted in a depolarization of the membrane potential and in an increased activity of uterine muscles (Jung, 1959).

Concerning abomasal smooth muscle cells, we have previously shown a higher contraction activity and higher amplitudes of contractions when extracellular K concentration was increased from 1 to $3,4,5$, and 6 mmol/L (Türck and Leonhard-Marek, 2010). The current study supports these observations. The reduction of the potassium concentration from 5.4 to $2 \mathrm{mmol} / \mathrm{L}$ showed a nominal decrease in contraction activity. The addition of $1 \mathrm{mmol}$ of $\mathrm{KCl} / \mathrm{L}$ to a total $3 \mathrm{mmol}$ of $\mathrm{KCl} / \mathrm{L}$ resulted in a nominal increase of contraction activity.

These changes in motility represent the effect of potassium on the basal membrane potential without affecting the frequency or the amplitudes of the slow waves. This is similar to the results of the in vitro motility experiments of Dengler et al. (1979), Jung (1959), and Türck and Leonhard-Marek (2010). They also observed no effects on the frequency of the contractions but on the force of contractions.

\section{Effect of Hypocalcemic Conditions}

Alterations in the total calcium concentration between 1.2 and $2.4 \mathrm{mmol} / \mathrm{L}$ affected neither the slow waves nor the motility of the abomasal smooth muscles in our study. In microelectrode recordings of the guinea-pig pylorus muscles, Van Helden et al. (2000) even changed to a calcium-free buffer solution for some minutes and also observed no differences in the characteristics of the slow waves. In in vitro motility experiments with the small intestine of rabbits, Grasa et al. (2004) showed a reduced frequency of contraction after $10 \mathrm{~min}$ of incubation in a calcium-free buffer solution.

Most of the cows with LDA suffer from a decreased blood calcium concentration (Delgado-Lecaroz et al., 2000), and Daniel (1983) was able to decrease the motility of the abomasum in vivo by reducing the blood calcium concentration to $1.2 \mathrm{mmol} / \mathrm{L}$. That means, however, that due to the presence of Ca-binding proteins in plasma, the ionized calcium concentration would have been around $0.6 \mathrm{mmol} / \mathrm{L}$, which is clearly under the level used in the in vitro experiments of our study. In the buffer solution used in the current study, a total Ca concentration of $1.2 \mathrm{mmol} / \mathrm{L}$ was correlated to a concentration of ionized $\mathrm{Ca}$ of $0.9 \mathrm{mmol} / \mathrm{L}$ (see Materials and Methods).

These considerations suggest that decreased calcium concentration needs some time to exert a negative effect on the activity of smooth muscles and that the calcium concentration has to be far below the physiological norm. A slight hypocalcemia alone does not seem able to cause depressed abomasal motility.

\section{Effect of Increased BHBA Concentration}

The effect of BHBA was tested under normo- and hypocalcemic conditions. According to different authors, a BHBA concentration above $0.9,1.0$, or 1.4 $\mathrm{mmol} / \mathrm{L}$ is related to health problems (Hoeben et al., 1997; LeBlanc et al., 2005; Stengärde et al., 2010). The concentration of $5 \mathrm{mmol} / \mathrm{L}$ used in the current study has been observed in ketotic animals (Hoeben et al., 1997). In contrast to our hypothesis, BHBA did not affect the frequency or the amplitude of the slow waves or the parameters of motility. This was true for normo- as well as hypocalcemic conditions. The bulls were found to be healthy before slaughter, so no calcium deficit can be assumed. Much the same could be said for the cows with LDA. Although these cows had partly developed hypocalcemia with the LDA, they had only been approved for the operation when their blood-calcium concentration had stabilized. Additionally, some of the cows no longer had an LDA at the time of the operation; therefore, enough time passed to optimize blood circulation to the smooth muscle cells. In ongoing experiments, however, with abomasal muscles from slaughtered wethers and from goats that had been kept on a low-Ca diet for $4 \mathrm{wk}$, the abomasal muscle cells show a reduced frequency of slow waves when exposed to a combination of low $\mathrm{Ca}$ and BHBA (our own observations).

These data suggest that BHBA by itself seems not to have a negative effect on the motility of healthy abomasal smooth muscle cells. A prolonged or severe exposition to a combination of low $\mathrm{Ca}$ and high BHBA concentrations might nevertheless be able to affect abomasal motility via a reduction in slow wave frequency.

\section{CONCLUSIONS}

Changes in membrane potential $\geq 5 \mathrm{mV}$ correlate with contractions of abomasal muscles. Hypokalemic conditions that can be observed around parturition, especially in connection with disease and reduced feed intake, reduce abomasal contraction activity via an effect on the membrane potential. An exclusive increase in BHBA by itself or slight hypocalcemia (ionized $\mathrm{Ca}$ $0.9 \mathrm{mmol} / \mathrm{L}$ ) seem not to have negative effects on the motility of healthy abomasal smooth muscle cells. A prolonged or severe exposition to a combination of low $\mathrm{Ca}$ and high BHBA concentrations might nevertheless be able to affect abomasal motility. The combined effects of hypocalcemia, ketosis, and hypokalemia point 
to a multifactorial pathogenesis of LDA, and treatments of hypokalemia and hypocalcemia should reduce the risk of the cows to develop LDA. Whereas anorectic cows are at risk to develop hypokalemia, especially if treated for ketosis with glucose, epidemiological studies help to define cows at risk to develop hypocalcemia; in both cases, oral electrolyte supplements can be used as prophylactic treatment (Oetzel, 2007).

\section{ACKNOWLEDGMENTS}

This study was supported by the German Research Foundation (DFG, Bonn, Germany).

\section{REFERENCES}

Constable, P. D., G. Y. Miller, G. F. Hoffsis, B. L. Hull, and D. M. Rings. 1992. Risk factors for abomasal volvulus and left abomasal displacement in cattle. Am. J. Vet. Res. 53:1184-1192.

Daniel, R. C. 1983. Motility of the rumen and abomasum during hypocalcaemia. Can. J. Comp. Med. 47:276-280.

Delgado-Lecaroz, R., L. D. Warnick, C. L. Guard, M. C. Smith, and D. A. Barry. 2000. Cross-sectional study of the association of abomasal displacement or volvulus with serum electrolyte and mineral concentrations in dairy cows. Can. Vet. J. 41:301-305.

Dengler, R., W. W. Hofmann, and R. Rudel. 1979. Effects of potassium depletion and insulin on resting and stimulated skeletal rat muscle. J. Neurol. Neurosurg. Psychiatry 42:818-826.

Dirksen, G. 1967. Gegenwärtiger Stand der Diagnostik, Therapie und Prophylaxe der Dislocatio abomasi sinistra des Rindes. Dtsch. Tierarztl. Wochenschr. 74:625-633.

Garcia-Lopez, P., V. Garcia-Marin, R. Martínez-Murillo, and M. Freire. 2009. Updating old ideas and recent advances regarding the Interstitial Cells of Cajal. Brain Res. Rev. 61:154-169.

Geishauser, T. 1995. Abomasal displacement in the bovine-A review on character, occurrence, aetiology and pathogenesis. Zentralbl. Veterinarmed. A 42:229-251.

Geishauser, T., K. Leslie, T. Duffield, and V. Edge. 1997. An evaluation of milk ketone tests for the prediction of left displaced abomasum in dairy cows. J. Dairy Sci. 80:3188-3192.

Geishauser, T., D. Reiche, and M. Schemann. 1998. In vitro motility disorders associated with displaced abomasum in dairy cows. Neurogastroenterol. Motil. 10:395-401.

Grasa, L., E. Rebollar, M. P. Arruebo, M. A. Plaza, and M. D. Murillo. 2004. The role of $\mathrm{Ca}^{2+}$ in the contractility of rabbit small intestine in vitro. J. Physiol. Pharmacol. 55:639-650.

Guschlbauer, M., S. Hoppe, F. Geburek, K. Feige, and K. Huber. 2010. In vitro effects of lidocaine on the contractility of equine jejunal smooth muscle challenged by ischaemia-reperfusion injury. Equine Vet. J. $42: 53-58$
Hara, Y., and J. H. Szurszewski. 1986. Effect of potassium and acetylcholine on canine intestinal smooth muscle. J. Physiol. 372:521537.

Hashitani, H., A. P. Garcia-Londoño, G. D. Hirst, and F. R. Edwards. 2005. Atypical slow waves generated in gastric corpus provide dominant pacemaker activity in guinea pig stomach. J. Physiol 569:459-465.

Hoeben, D., R. Heyneman, and C. Burvenich. 1997. Elevated levels of $\beta$-hydroxybutyric acid in periparturient cows and in vitro effect on respiratory burst activity of bovine neutrophils. Vet. Immunol. Immunopathol. 58:165-170.

Jung, H. 1959. Der Einfluß veränderter extracellulärer K-Konzentrationen auf das Ruhepotential und die Motilität des Uterus. Arch. Gynakol. 192:96-108.

Kito, Y., and H. Suzuki. 2003. Electrophysiological properties of gastric pacemaker potentials. J. Smooth Muscle Res. 39:163-173.

Kito, Y., and H. Suzuki. 2007. Effects of temperature on pacemaker potentials in the mouse small intestine. Pflugers Arch. 454:263275

LeBlanc, S. J., K. E. Leslie, and T. F. Duffield. 2005. Metabolic predictors of displaced abomasum in dairy cattle. J. Dairy Sci. $88: 159-170$.

Massey, C. D., C. Wang, G. A. Donovan, and D. K. Beede. 1993. Hypocalcemia at parturition as a risk factor for left displacement of the abomasum in dairy cows. J. Am. Vet. Med. Assoc. 203:852-853.

Oetzel, G. R. 2007. Oral nutritional supplements for parturient dairy cows. Pages 93-96 in Proc. 40th Annu. Conf. Am. Assoc. Bovine Pract., Vancouver, Canada. University of Wisconsin, Madison.

Rolle, U., A. Piaseczna-Piotrowska, and P. Puri. 2007. Interstitial cells of Cajal in the normal gut and in intestinal motility disorders of childhood. Pediatr. Surg. Int. 23:1139-1152.

Stengärde, L., K. Holtenius, M. Tråvén, J. Hultgren, R. Niskanen, and U. Emanuelson. 2010. Blood profiles in dairy cows with displaced abomasum. J. Dairy Sci. 93:4691-4699.

Suzuki, H. 2000. Cellular mechanisms of myogenic activity in gastric smooth muscle. Jpn. J. Physiol. 50:289-301.

Suzuki, H., and G. D. Hirst. 1999. Regenerative potentials evoked in circular smooth muscle of the antral region of guinea-pig stomach. J. Physiol. 517:563-573.

Türck, G., and S. Leonhard-Marek. 2010. Potassium and insulin affect the contractility of abomasal smooth muscle. J. Dairy Sci. 93:3561-3568.

Van Helden, D. F., M. S. Imtiaz, K. Nurgaliyeva, P.-Y. von der Weid, and P. J. Dosen. 2000. Role of calcium stores and membrane voltage in the generation of slow wave action potentials in guinea-pig gastric pylorus. J. Physiol. 524:245-265.

Vanheel, B., and J. Breyne. 2004. Endothelium-dependent hyperpolarization in small gastric arteries. Cardiovasc. Res. 63:331-337.

Ward, J. L., D. F. Smith, S. L. Fubini, and D. M. Deuel-Aromando. 1994. Evaluation of abomasal outflow diversion as an experimental model of hypochloremic metabolic alkalosis in lactating cows. Can. J. Vet. Res. 58:13-19. 